THURSDAY, JULY 24, IS73

\section{THE ENDOIVIIENT OF RESEARCH} III.

${ }^{\mathrm{T}}$ is probable that though the main proposition here 1 advocated, that original workers in the Sciences deserve, on public grounds, a recognised position and pecuniary support, will not meet with much opposition from any quarter, the means by which this desirable end is chiefly proposed to be attained will not be acquiesced in with equal readiness. Englishmen have been so long accustomed to regard their Universities as merely high schools of liberal education, and the independent growth of modern Science in this country has been so rapid and vigorous, that to manyworthy persons it will seem nothing better than a Utopian dream to attempt to re-establish the genuine pursuit of scientific knowledge as an end in itself at our ancient seats of learning. Those, however, who know something about the system of a. German University, and are acquainted with the former history of Oxford and Cambridge, will not consider the attempt to be of such a hopeless character. The present time also affords an admirable opportunity of urging upon public attention a fundamental reform in the direction above indicated. The Universities have of late years been losing many of the peculiarities which they once so warmly cherished, and at the same time their revenues have been increasing to an enormous extent. The same Government which passed a Bill to pronounce them national and not ecclesiastical establishments, has also issued a Royal Commision to inquire into the extent and distribution of their endowments. Now that the nation has established its claim to remodel the Universities solely with a view to the public interest, and is taking stock, as it were, of the property which has fallen under its disposal, the very occasion has come when scientific men should formulate their demands on behalf of those public interests which the practical politician is likely to neglect. It must, moreover, be borne in mind that the impulse in this direction must come from without, for although it will not be difficult to prove that no less benefit would accrue to the Universities themselves than to the cause of Science from the scheme herein advocated, yet the most advanced academical reformers do not seem to have got beyond the notion of extending and perfecting the professorial functions.

We propose then to show at some length that the Endowment of Research should naturally take a leading place in the reconstruction of the University system which appears to be close at hand, and to indicate in what manner such endowment may most readily be carried into effect. For this purpose it will not be necessary to reveal the many minor abuses which the reforms of twenty years ago failed to remove, but it will be necessary to adopt the more difficult task of sketching out the true conception of what a University should be, and of considering the comparative claims to endowment of teaching and of study.

Without any attempt to prejudge the matter, or to awake the dormant controversy as to the original meaning of the word, it may be safely laid down that a University

No. 195-Vol. viri. is an institution composed of the most competent teachers and the most promising students, on which the State, in consideration of its diligently promoting the higher education, confers a lofty position and important privileges. That such an institution should enjoy large endowments is evidently not of the essence of its nature, for the Universities of old were uniformly most famous when they were least rich : it is, however, absolutely necessury for the healthy activity of its functions that it should not be so encumbered with wealth as to be disposed to lavish sinecures upon its favourite members. It is evident, also, that it will forfeit its trust as the home of Culture and of Science, and will degenerate into a lyceum for the adult sons of the well-to-do classes, unless it continually maintains itself on a level with the ever-advancing boundaries of human knowledge, and that just so far as it lags behind it will exercise a mischievous influence on the simple public, who continue to rely upon its treacherous authority. Further, it is of great importance that the original institution, on which alone the rank was bestowed, and which alone deserves the high privileges, should not be absorbed by the growth of a number of parasitic institutions, whose interests and aims may be not identical with or even analogous to its own. But above all other symptoms of decay that a University can show, is to be placed its rejection of the highest branches of knowledge which the progressive activity of human thought is ever compre. hending within the domain of Science. To this danger the most ancient and the most wealthy Universities are naturally the most exposed. Their antiquity leads them to regard the erudition which they have inherited through many centuries as synonymous with real knowledge, and their wealth is used (where it is not misused) to afford encouragement only to those kinds of learning which their traditions have sanctified. In brief, a false University would be an institution which is content merely to satisfy the demand for teaching which custom approves, and which nezlects as a hindrance to its tuitional duties the higher knowledge which it was originally founded to promote.

To recall such a University to the true conception of its duties no mere mechanical changes with reference to its internal organisation will be sufficient. It has lost the spirit of disinterested study which first gave it life, and the atmosphere of intellectual activity under which alone it can flourish. It requires that new vigour should be poured into it, and a new order of workers established within its limits. It requires to be relieved of the burden of part of its wealth, in order that it may receive back again greater advantages than it can give. By endowing research in all those departments of knowledge to which the scientific method has been already extended, and by reserving the power of similar endowment for those other departments of knowledge which will, no doubt, before long be similarly reduced to order and law, Oxford and Cambridge may yet regain the proud position which was once theirs, as " bodies of learned men devoting their lives to the cultivation of Science, and the direction of academical teaching."

To point cut more particularly the source from which the endowments of research should be drawn, it will be necessary to revive the original distinction between the Universities and the Colleges of which they may be said to be now composed. To raise the University proper at 
the expense of the individual Colleges, has long been a favourite project with academical reformers, yet no one yet appears to propose any more radical scheme than an augmentation in the number of University Professors, and a diminution in the influence of College tutors. Against any such scheme, however carefully elaborated, there arise the old objections that an improvement in the mechanism of teaching is not the main reform of which the Universities stand in need, and that the endowment of more teachers will not remedy the crying evil which has so lamentably hindered the advance of purely scientific investigation in this country. The circumstance that the Universities are comparatively poor, while many of the Colleges are very rich, and an awakening conviction that the Colleges exist for the Universities, and not the Universities for the Colleges, would seem to have suggested the above proposal: whereas the smallest historical knowledge of the objects with which the Colleges were originally founded, would reveal the curious circumstance that the first benefactors had a truer conception of the manner in which knowledge ought to be endowed, than have the modern recipients of their benefits. Nothing can be more certain, though nothing is more frequently denied by those whose duty it is to be better informed, than that the majority of the great Colleges were not founded to be boarding schools for teachers and students, subordinate to the University curriculum, but to be homes at the central seats of learning, where life-long students might be supported while acquiring all the knowledge of the age, and augmenting the store of learning which they had there inherited. According to the old Oxford tradition, she could boast in the fifteenth century before there was ever a wealthy College that she had thousands of students living in hundreds of private halls. Many of the early Colleges did not include at all in their arrangements those whom we should now call Undergraduates, some of those which did do so allowed for a teaching staff independent of the body of Fellows, and it is within modern memory that many Colleges have had more Fellows than Undergraduates on their books. All these facts, and there are many similar ones, go to prove decisively that, in the language of Mr. Mark Pattison, "the Colleges were in their origin endowments not for the elements of a general liberal education, but for the prolonged study of special and professional faculties by men of riper age: and that so far from it being the intention of a Fellowship to support its holder as a teacher, it was rather its purpose to relieve him from the drudgery of teaching for a maintenance, and to set him free to give his whole time to the studies and exercises of his faculty." The wish of the Founders, that is to say, when harmonised with the wants of the present age, and interpreted into the language of modern science, was to afford the means of living and the instruments of work to those who pledge their lives to the unremunerative task of scientific investigation, and original research.

Surely then, if the influential and wealthy nembers of our Universities have at heart the real interest of their Institutions, or retain any veneration for the express intentions of their benefactors, they should not be the last to join in the patriotic object of raising the scientific reputation of this country, and increasing in manifold unseen ways the elcments of our national greatness.

\section{ALEXANDER VON HUMBOLDT}

Life of Alexanier von Humboldt, compiled by F. Löwenberg, Robert Ave-Lallemant, and Alfred Dove. Edited by Professor Karl Bruhns. Translated by J. and C. Lassell. 2 vols. (London : Longmans, 1873.)

W ${ }^{\mathrm{E}}$ cordially welcome this admirable translation of the only biography of A. v. Humboldt that has yet appeared possessing any authentic or scientific value. Humboldt's own definitely expressed aversion to biographical notices, whether in regard to himself or his friends, the fact of his having outlived nearly all his blood-relations and the greater number of the contemporaries of his earlier working years, together with other causes, combined, for a time, to retard the appearance of a trustworthy life of this remarkable man.

The want of such a work was, however, strongly felt, and at the Congress of Astronomers convened at Vienna on Sept. 14, I869, in honour of the centenary of A. v. Humboldt's birth, Dr. Karl Bruhns, Director of the Observatory at Leipng, laid before the meeting the prospectus of a Scientific Biography of their great countryman, for which he demanded their active co-operation. The result of this appeal and of his own editorial labours, was the appearance last year, in Germany, of the work of which the present excellent translation gives us two volumes. The third volume of the original, which consists of critical résumés by various writers of the state of different branches of the physical and natural sciences, with notices of Humboldt's contributions to each, has been omitted by the translators, on the ground that the facts were treated of with sufficient minuteness in the general biography. On less good grounds, as it appears to us, they have also omitted from the last section of the second volume, the comprehensive catalogue of his published writings, of which upwards of 600 are enumerated in this list.

Humboldt's life, like the work devoted to its exposition, resolves itself into two distinct parts or periods. The first of these is characterised by intense and incessant activity in the acquisition of knowledge, the second by the quiet mature elaboration of the results of earlier study and observation ending in a thirty years' term of comparative stagnation under the depressing influences of honorary court servitude.

Alexander v. Humboldt was born at Berlin, in 1769 , and together with his elder brother Wilhelm, was prepared under excellent private tutors for his university career at Frankfort, A. O., where he matriculated in 1787. He had already then shown that craving for the accumulation of facts which he retained to his latest years, and from his boyhood had been distinguished for his love of observing and collecting natural history objects, and his inaptitude for acquiring the exact classical scholarship for which his brother evinced such marked ability. Botany was Alexander's first love, and the earliest of his voluminous literary productions was a treatise in French which appeared anonymously at Berlin, in 1789 , in the Gazettc Literaire, entitled, "Sur le Bohon-Upas, par un jeune Gentilhomme de Berlin." This composition was, however, rapidly followed by papers on the flora and geology of the Rhine lands, and other districts which he visited in the course of the few short intervals of cessation 